\title{
Purification of Extracellular Collagenase from Pseudomonas sp: Remarkable Collagenolytic Activity
}

\author{
Manisha Gautam* and Wamik Azmi \\ Department of Biotechnology, Himachal Pradesh University, India
}

Submission: May 30, 2017; Published: July 20, 2017

*Corresponding author: Manisha Gautam, Department of Biotechnology, Himachal Pradesh University, Summer Hill, Shimla (HP) 171005, India, Tel: +91-177-2831948; Fax: +91-177-2832154; Email:manisha.gautam21@gmail.com/wamikazmi@rediffmail.com

\begin{abstract}
A collagenase from Pseudomonas sp. was purified upto 13-fold with a yield of 3.6\% using hydrophobic interaction chromatography. Molecular weight of $34 \mathrm{kDa}$ collagenase was identified using sodium dodecyl sulfate-polyacrylamide gel electrophoresis method. Gelatin and collagen substrates were used in the characterization of purified collagenase. The optimum temperature and pH were $45^{\circ} \mathrm{C}, \mathrm{pH} 7.5$ for gelatin and $50{ }^{\circ} \mathrm{C}, \mathrm{pH} 8.5$ for collagen respectively. The collagenase activity was highly inhibited by Hg2+, Pb2+, EDTA, DTT at concentration of $1 \mathrm{mM}$ and significant negative effect of $\mathrm{Fe} 2+, \mathrm{Cu} 2+$ and $\mathrm{Co} 2+$ was observed at similar concentration. However, $\mathrm{Ca} 2+(1 \mathrm{mM})$ and PEG (1mM) increased the enzyme activity. The Pseudomonas based collagenase have the ability to hydrolyse protein substrates. The $\mathrm{K}_{\mathrm{m}}$ and $\mathrm{V}_{\max }$ values for the purified collagenase were found to be $1.65 \mathrm{mg} / \mathrm{mL}$ and $2.12 \mathrm{U} / \mathrm{mL}$ with collagen substrate while for gelatin substrate values were $6.60 \mathrm{mg} / \mathrm{mL}$ and $6.58 \mathrm{U} / \mathrm{mL}$, respectively.
\end{abstract}

Keywords: Collagen; Pseudomonas; Collagenase; Gelatine; Microorganism

Graphical Abstract (Figure 1)

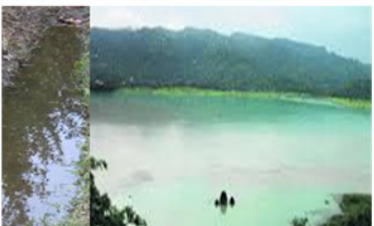

Soil from different places

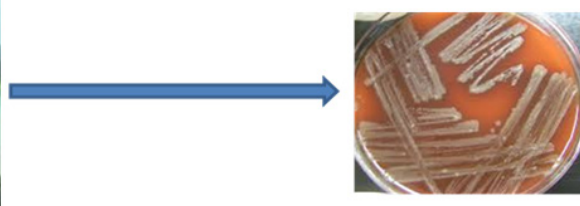

Pseudomonassp.

$45^{\circ} \mathrm{C}$ a

13-fold with a yield of $3.6 \%$ using hydrophobic interaction chromatography.

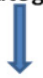

and pH 8.5 for collagen respectively Production, purification and Gelatin and collagen substrates characterization of extracellula Collagenase

34 kDa collagenase

Figure 1: Graphical abstract.

Highlights
A. Screening of soil/sewage samples for the hyper producer strain with maximum collagenase activity
B. Strain was identified as Pseudomonas sp.
C. Determination of protein content and collagenase activity
D. Production, purification and characterization of collagenase enzyme from Pseudomonas sp. 


\section{Introduction}

Abundantly found extracellular matrix protein (collagen) plays critical roles in the formation of tissues and organs [1]. Collagenases are responsible for the degradation of helical regions of native collagen into small fragments due to its proteolytic activity. However, the tissue collagenases are only responsible for the first step of the catabolism of collagen [2]. The most extensive research has been carried out on the bacterial collagenases due to their broad substrate specificities and abilities to degrade native and denatured collagens [3]. Bacterial collagenases hydrolyze both water-insoluble and water-soluble collagens [4]. Collagenases hold the industrial applications due to its proteolytic enzymes activity. Collagen is partly responsible for toughness of red meats and have been utilized as tenderizers in the food industry $[5,6]$. They are also used in leather industry due to its applications in fur and hide tanning to ensure a uniform dying to leathers $[7,8]$. However, the most common uses of this enzyme is appears to be in medicine e. g. used to treat burns and ulcers $[9,10]$, to eliminate scar tissue [11] and also in transplantation of specific organs $[12,13]$. The importance of Pseudomonas family in human disease is well known, especially in nosocomial infections and in patients being treated with corticosteroids, radiation therapy, antineoplastic drugs and prolonged antimicrobial therapy. Pseudomonas sp. produces a variety of extracellular substances that may play a role in the disease process particularly the proteolytic enzymes $[14,15]$. Some of these enzymes attack coiled polypeptide chains but are inactive against collagen molecules. Hence, the true collagenolytic activity can only be analyzed using the collagen as substrate. In the present study, we have described the purification and characterization of the collagenase from the extracellular culture filtrate of the Pseudomonas sp.

\section{Materials and Methods}

\section{Microorganism}

A total 27 soil/sewage samples were collected from local area of fish market and slaughterhouse of Bilaspur and Shimla districts, Himachal Pradesh (India). They were screened for the hyper producer strain with maximum collagenase activity and one of them found suitable for study. The strain was identified as Pseudomonas sp. Collagenase from Pseudomonas sp. was found to be extracellular in nature. Hence, cell free supernatant obtained from $24 \mathrm{~h}$ old culture broth was used as crude enzyme. Collagenase was produced with a medium having $\mathrm{pH} 7.0$, sucrose 1.0 tryptone 1.0 , yeast extract 0.25 , meat extract 0.2 and gelatin 0.3 $\%, \mathrm{w} / \mathrm{v}$ respectively. The production medium was inoculated with $4 \%$ (v/v) inoculum of Pseudomonas sp. and incubated at $37^{\circ} \mathrm{C}$ for $24 \mathrm{~h}$ at $150 \mathrm{rpm}$. The culture broth was centrifuged at $15000 \mathrm{~g}$ for $15 \mathrm{~min}$, and supernatant obtained was used as crude enzymes. Protein content and collagenase activity was determined in crude enzyme and it was purified by applying different protein precipitation methods and chromatography techniques.

\section{Enzyme purification}

The supernatant of culture was precipitated with saturated ammonium sulphate $(40-60 \% \mathrm{w} / \mathrm{v})$. The precipitate was separated by centrifugation and dissolved in $0.1 \mathrm{M}$ Tris-HCl buffer (containing $30 \mathrm{mM}$ calcium chloride, $\mathrm{pH}$ 7.5). The enzyme solution was dialyzed against same reaction buffer for $12 \mathrm{~h}$ and stored at $4{ }^{\circ} \mathrm{C}$. The sample was then subjected for hydrophobic ion chromatography on octyl sepharose column for the separation of the protein mixtures. The column was equilibrated with binding buffer $[0.1 \mathrm{M}$ Tris- $\mathrm{HCl}$ buffer containing $\left.1.5 \mathrm{M}\left(\mathrm{NH}_{4}\right) 2 \mathrm{SO}_{4}(\mathrm{pH} 7.5)\right]$ at until the baseline was stable (minimum of 2 column volumes). Protein fractions were eluted with decreasing salt gradient concentration of $\left(\mathrm{NH}_{4}\right) 2 \mathrm{SO}_{4}(1.5 ; 1.25 ; 1.00 ; 0.75,0.50$ and $0.25 \mathrm{M})$ in Tris- $\mathrm{HCl}$ buffer, $\mathrm{pH} 7.5$ at a rate of $5 \mathrm{~mL} / \mathrm{min}$. The fractions having collagenase activity were pooled together and concentrated. Finally, the pooled collagenase activity fractions were stored and used to establish its purity.

\section{Assay of collagenase activity}

Collagenase activity of Pseudomonas sp. was assayed using different substrates including gelatin and collagen. Initially, it was measured using gelatin substrate [16]. The standard reaction mixture [ $0.3 \mathrm{~mL}$ of gelatine, $0.2 \mathrm{~mL}$ of Tris-HCl buffer $(\mathrm{pH} 7.5)$ and $\left.50 \mathrm{mM} \mathrm{CaCl}_{2}\right]$ was incubated with $100 \mu \mathrm{L}$ cell free supernatant enzyme at $37^{\circ} \mathrm{C}$ for $30 \mathrm{~min}$. Trichloroacetic acid $(0.6 \mathrm{~mL})$ was added to stop the reaction and released amount of free amino groups was measured using ninhydrin method [17]. Collagenase activity was also measured using collagen substrates as described by Endo et al. [18]. The reaction mixture [0.3mg collagen (from bovine a chilles tendon) in $500 \mu \mathrm{L}, 0.1 \mathrm{M}$ Tris- $\mathrm{HCl}$ buffer and $50 \mathrm{mM}$ $\mathrm{CaCl}_{2}$ (pH 7.5)] was incubated with $100 \mu \mathrm{L}$ enzyme at $37{ }^{\circ} \mathrm{C}$ for $30 \mathrm{~min}$. The released amount of free amino groups was also measured using ninhydrin method [17]. The amino acid composition of denatured collagen is similar to gelatine. Collagenase has the ability to hydrolyze gelatine and was used as substrate for initial screening of collagenase producing micro-organisms.

\section{Protein determination}

Protein was analysed and estimated using Bradford's method (1976) [19].

\section{Molecular weight determination}

The polyacrylamide gel electrophoresis was done to analyze the molecular weight and purity of the protein isolated from hydrophobic interaction chromatography under denaturating conditions (SDS-PAGE) with $10 \%$ polyacrylamide gels [20,21].The molecular weight of the protein marker ranged from $11 \mathrm{kDa}$ to $245 \mathrm{kDa}$ and middle range molecular weight SDS-protein marker (Genei Pvt. Ltd., Banglore) was used for subunit molecular mass analysis of collagenase of Pseudomonas sp. Enzymes activity in situ was determined using zymogram and method used by Tyagi, 1993. Protein samples $(0.165 \mathrm{mg} / \mathrm{mL})$ were mixed with buffer free $\beta$-mercaptoethanol and applied to $10 \%$ native-PAGE, which 
had been copolymerized with $0.25 \%(\mathrm{w} / \mathrm{v})$ gelatin (Sigma). The gel was incubated overnight at room temperature in a reaction buffer [100mM Tris- $\mathrm{HCl}, 30 \mathrm{mM} \mathrm{CaCl}{ }_{2}$ and $\left.\mathrm{pH} 7.5\right]$. After incubation the gel was stained with Coomassie Brilliant Blue R-250. The clear zones appearing on the gel indicated the location of proteins exhibiting proteolytic or collagenolytic activities.

\section{Characterization of purified collagenase (Pseudomo- nas sp.) using gelatin and collagen substrates and com- parative study with commercial collagenase $(C$. histo- lyticum)}

The various reaction parameters (buffer $\mathrm{pH}$, role of calcium ions, molarity of calcium ions, molarity of buffer, reaction temperature, incubation time, substrate specificity, substrate concentration, temperature stability of enzymes and role of metal ions and inhibitors) were analyzed to find out the optimum reaction conditions for maximum activity in purified collagenase of Pseudomonas sp. The purified collagenase was compared with commercial collagenase using gelatin and acid hydrolysed collagen $(0.2 \%, \mathrm{w} / \mathrm{v})$ as substrates for assay. The collagenase activity was measured using $50 \mu \mathrm{L}$ of purified and commercial collagenase having s $0.165 \mathrm{mg} / \mathrm{mL}$ protein.

\section{Effect of buffer $\mathrm{pH}$}

Collagenase activity of the purified enzyme was measured using Tris- $\mathrm{HCl}$ buffer $(100 \mathrm{mM})$, the $\mathrm{pH}$ of the buffer was varied from 7.0-9.0 in order to find out the most suitable $\mathrm{pH}$ for the enzyme. The collagenase activity in purified and commercial collagenase was determined in each buffer $\mathrm{pH}$. The reaction mixture was incubated with both substrates $(0.2 \%, \mathrm{w} / \mathrm{v}$; gelatin or collagen) at $450 \mathrm{C}$ for $30 \mathrm{~min}$.

\section{Role of calcium ions in buffer}

The calcium chloride was reported to be important for the stability of the collagenase. In order to establish the role of calcium ions on the collagenase activity, calcium chloride was added at $30 \mathrm{mM}$ concentration in $100 \mathrm{mM}$ Tris- $\mathrm{HCl}$ buffer ( $\mathrm{pH} 7.0-9.0$ ).

\section{Effect of buffer molarity}

The molarity of the Tris- $\mathrm{HCl}$ buffer was varied $(25-200 \mathrm{mM})$ for assay of purified and commercial collagenase. The reaction was performed with collagen (buffer $\mathrm{pH} 8.5$ ) and $0.2 \%$ gelatin (buffer $\mathrm{pH} 7.5$ ) at $45^{\circ} \mathrm{C}$ for $30 \mathrm{~min}$.

\section{Effect of reaction temperature and incubation time}

The effect of temperature on collagenase activity of the purified enzyme in the presence of $80 \mathrm{mM} \mathrm{CaCl} 2$ in Tris- $\mathrm{HCl}$ buffer of $\mathrm{pH} 7.5(100 \mathrm{mM})$ was measured with gelatin at different incubation temperatures $\left(25-60^{\circ} \mathrm{C}\right)$. However, Tris- $\mathrm{HCl}$ buffer $(100 \mathrm{mM}$, $\mathrm{pH}$ 8.5) with $70 \mathrm{mM}$ calcium chloride was used for collagen substrate. The reaction mixture containing purified and commercial enzyme was incubated with both substrates for $60 \mathrm{~min}$ and collagenase activity was determined at regular interval of $5 \mathrm{~min}$.

\section{Substrate specificity}

Collagenase activity on various protein substrates $(0.2 \%$, $\mathrm{w} / \mathrm{v}$ ) such as gelatin, casein, bovine serum albumin and hydrolysed collagen were assayed by mixing $0.50 \mu \mathrm{L}$ of enzyme and $300 \mu \mathrm{L}$ of substrate (casein, gelatin and fibrin) and $250 \mu \mathrm{L}$ Tris- $\mathrm{HCl}$ buffer. The reaction mixture was incubated for $30 \mathrm{~min}$ at $45^{\circ} \mathrm{C}$ and collagenase activity was measured.

\section{Determination of kinetic properties}

The apparent Michaelis-Menten constant $\left(\mathrm{K}_{\mathrm{m}}\right)$ and maximum velocity number $\left(\mathrm{V}_{\max }\right)$ were calculated using different concentrations $(1-10 \mathrm{mg} / \mathrm{mL})$ of collagen and gelatin. Enzymes were incubated at $450 \mathrm{C}$ for $20 \mathrm{~min}$. Lineweaver-Burk plot between $1 / \mathrm{V}$ and $1 /[\mathrm{S}]$ was used for determination of $\mathrm{Km}$ and Vmax values.

\section{Effect of metal ions, inhibitors and additives on colla-} genase activity

The effects of various metal ions and inhibitors (Co2+, $\mathrm{Na}+$, $\mathrm{K}+, \mathrm{Ca} 2+, \mathrm{Mg} 2+, \mathrm{Cu} 2+, \mathrm{Mg} 2+, \mathrm{Zn} 2+, \mathrm{Pb} 2+, \mathrm{Ag} 2+, \mathrm{Fe} 2+$, Urea, SDS, PEG, DTT, EDTA and PMSF were tested on purified and commercial enzyme activity, which were used in $1 \mathrm{mM}$ concentration for reaction mixture. The residual activity was determined as a percentage of activity in control sample without the addition of metal ions.

\section{Results and Discussion}

\section{Purification of collagenase}

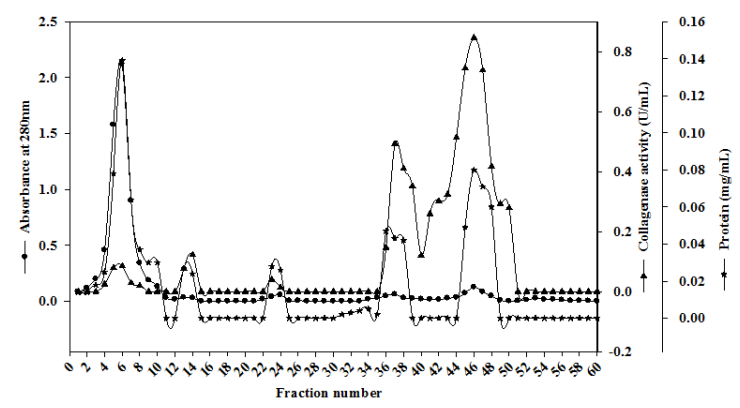

Figure 2: Elution profile of collagenase from Pseudomonas $\mathrm{sp}$

Table 1: Summary of collagenase purification from Pseudomonas sp.

\begin{tabular}{|c|c|c|c|c|}
\hline $\begin{array}{c}\text { Purification } \\
\text { steps }\end{array}$ & $\begin{array}{c}\text { Total activ- } \\
\text { ity (U) }\end{array}$ & $\begin{array}{c}\text { Specific } \\
\text { activity } \\
\text { (U/mg) }\end{array}$ & $\begin{array}{c}\text { Purifica- } \\
\text { tion Fold }\end{array}$ & Yield (\%) \\
\hline Crude Enzyme & 352.5 & 2.66 & 1 & 100 \\
\hline $\begin{array}{c}\text { Ammonium } \\
\text { sulphate pre- } \\
\text { cipitation }\end{array}$ & 32.98 & 3.12 & 1.17 & 9.3 \\
\hline $\begin{array}{c}\text { Octyl-sephrose } \\
\text { Chromatogra- } \\
\text { phy }\end{array}$ & 12.69 & 26.43 & 13 & 3.6 \\
\hline \multicolumn{1}{|c|}{} & & & \\
\hline
\end{tabular}


The Purification of collagenase from Pseudomonas sp. has been given in Table 1 and Figure 2. Enzyme was purified upto 13 -fold with a yield of $3.6 \%$. We have used the octyl sepharose coloumn chromatography for purification while Kristjansson and Sakurai co-workers used phenyl-substituted and more hydrophobic butyl substituted agarose column respectively [22,23].

The active fractions (with high specific activity) were pooled together and assessed for purity by electrophoresis. Molecular weight was estimated by electrophoresis under denaturating (SDS-PAGE) and non-denaturing (native-PAGE) conditions [20]. The analysis of the gel run under denaturing conditions after hydrophobic ion chromatography, revealed single band of molecular weight approximately $34 \mathrm{kDa}$ (Figure 3). The purified fractions were also subjected to gelatin zymogram and showed clear bands formed due to the digestion of gelatin used in the gel during polymerization (Figure 3).

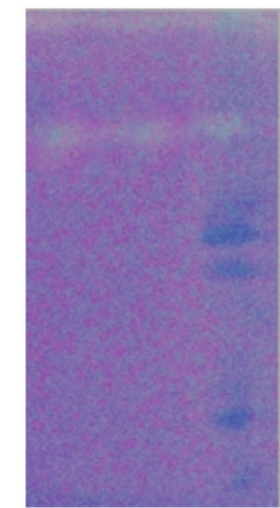

3a

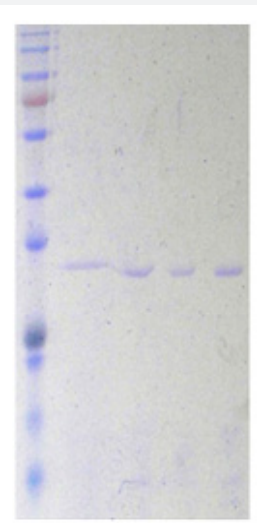

$3 b$
Figure 3: SDS-PAGE profille (12\%w/v) (2b) Native-PAGE gelatin zymogram $(10 \% \mathrm{w} / \mathrm{v})$ :SDS-PAGE and native-PAGE profile for collagenase from Pseudomonas sp. (a) SDS-PAGE profile (Lane 1-Molecular marker, Lane 2, 3, 4, 5 Purified protein) (b) Native-PAGE gelatin zymogram (Lane 3- Dialysed protein, Lane 1 and 2 -Purified protein).

\section{Characterization of purified collagenase from Pseudo- monas sp.}

The various reaction parameters were analyzed to explore the optimum reaction conditions for maximum activity of purified collagenase of Pseudomonas sp. and its comparison with commercial collagenase by using gelatin and collagen $(0.2 \%, \mathrm{w} / \mathrm{v})$. Comparative effect of effect of buffer $\mathrm{pH}$, role of $\mathrm{Ca} 2+$, buffer molarity, incubation temperature, incubation time, substrate specificity, kinetic properties and effect of metal ions on purified and commercial collagenase were studied and found that Tris-HCl buffer $(0.1 \mathrm{M})$ with pH 8.5 was found optimum for the activity of purified and commercial enzyme with collagen substrate while gelatin substrate showed maximum activity at $\mathrm{pH}$ 7.5. Activity altered with change in $\mathrm{pH}$ and this may be due to the fact that active site losses its affinity towards substrate (Figure $4 \& 5$ ). The purified collagenase showed more activity than commercial at optimized $\mathrm{pH}$ with gelatin and collegen substrate.

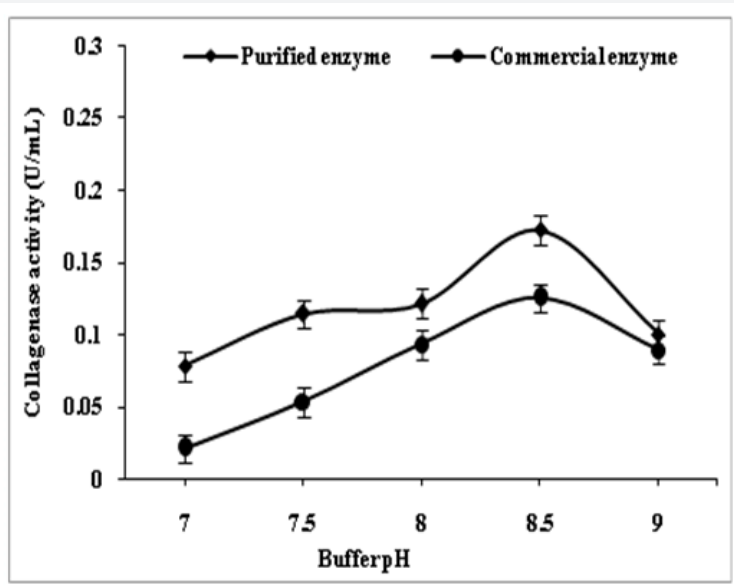

Figure 4: Effect of buffer $\mathrm{pH}$ on activity of purified and commercial collagenase with collagen substrate.

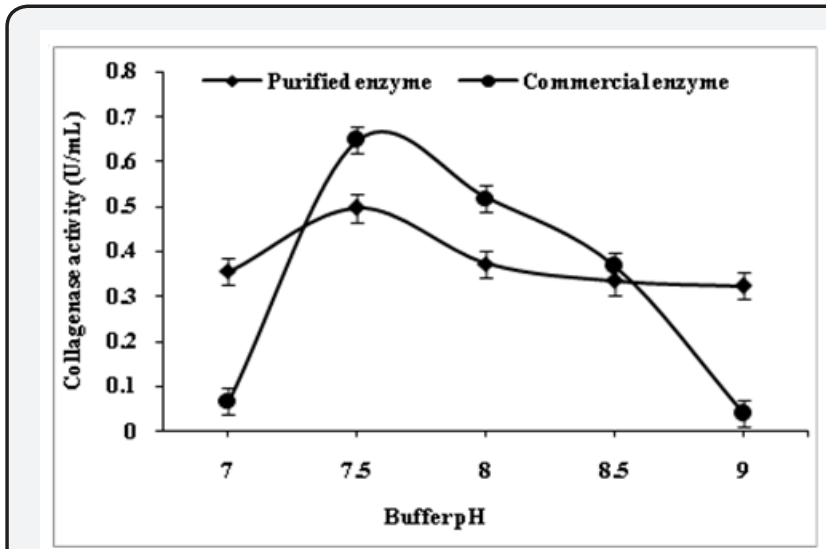

Figure 5: Effect of buffer $\mathrm{pH}$ on activity of purified and commercial collagenase with gelatin substrate.

\section{Role of calcium chloride in buffer}

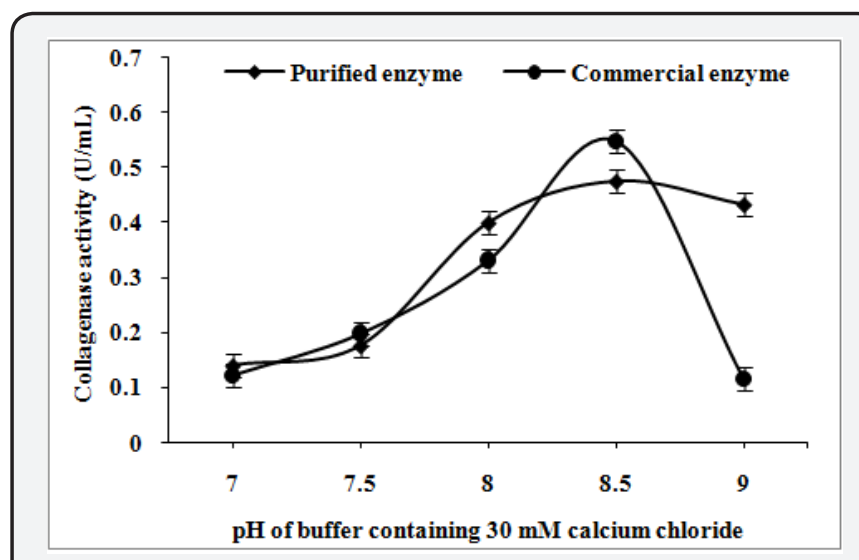

Figure 6: Role of calcium chloride in Tris- $\mathrm{HCl}$ buffer $(0.1 \mathrm{M})$ on activity of purified and commercial collagenase using collagen substrate.

The Tris-HCl buffer (7.0-9.0 pH) were supplemented with calcium chloride $(30 \mathrm{mM})$ to analyze the role of $\mathrm{Ca} 2+$ in the buffer for collagenase activity from Pseudomonas sp. The purified and commercial collagenase has showed $0.475 \mathrm{U} / \mathrm{mL}$ and $0.547 \mathrm{U} / \mathrm{mL}$ as maximum collagenase activity, in Tris- $\mathrm{HCl}$ buffer at $\mathrm{pH} 8.5$ us- 
ing collagen substrate (Figure 6) while gelatin substrate showed $0.727 \mathrm{U} / \mathrm{mL}$ and $1.155 \mathrm{U} / \mathrm{mL}$ respectively (Figure 7). Calcium ion helps in the enhancement of enzyme activity in both [24].

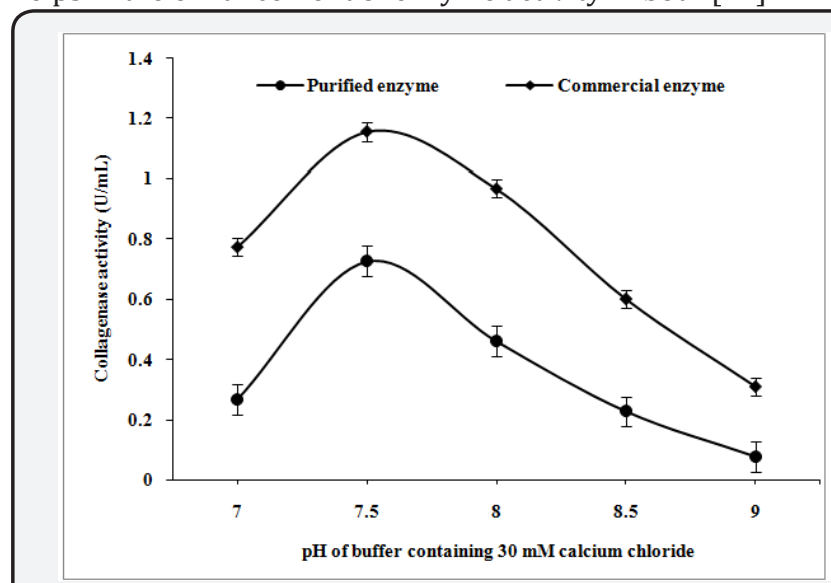

Figure 7: Role of calcium chloride in Tris-HCl buffer $(0.1 \mathrm{M})$ on activity of purified and commercial collagenase using gelatin substrate.

\section{Effect of buffer molarity}

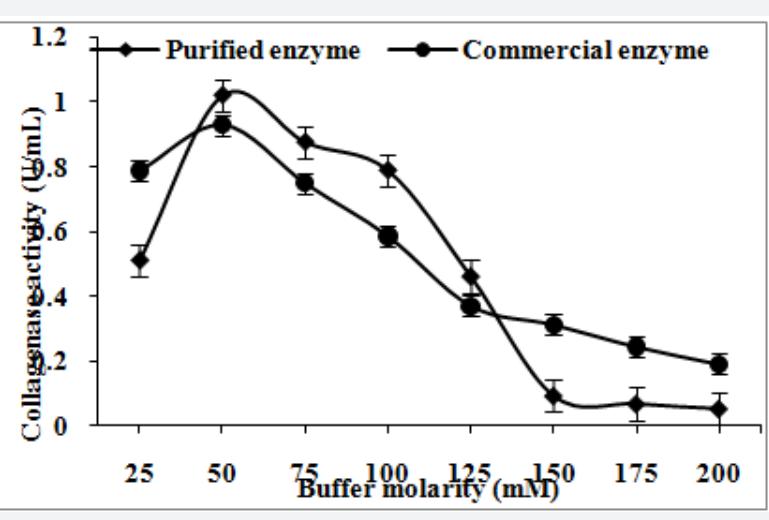

Figure 8: Effect of Tris- $\mathrm{HCl}$ buffer ( $\mathrm{pH} 8.5$ ) molarity on activity of purified and commercial collagenase with collagen substrate.

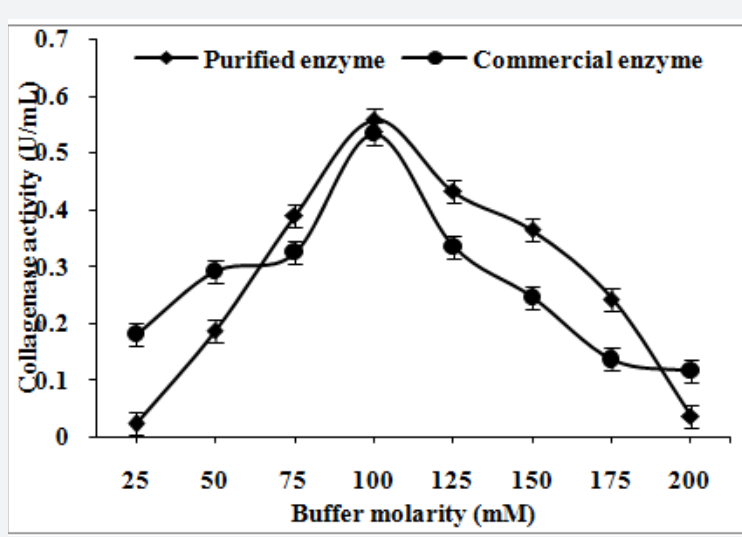

Figure 9: Effect of Tris-HCl buffer ( $\mathrm{pH} 7.5)$ molarity on activity of purified and commercial colagense with gelatin substrate.

Purified enzyme of Pseudomonas sp. and commercial collagenase exhibited the maximum enzyme activity of $0.173 \mathrm{U} / \mathrm{mL}$ and $0.126 \mathrm{U} / \mathrm{mL}$, respectively, at $50 \mathrm{mM}$ concentration of Tris- $\mathrm{HCl}$ buffer ( $\mathrm{pH}$ 8.5) with collagen as substrate (Figure 8). However, the incubation of purified enzyme of Pseudomonas sp. and commercial collagenase with gelatin showed maximum enzyme activity $(0.497 \mathrm{U} / \mathrm{mL}$ and $0.648 \mathrm{U} / \mathrm{mL}$, respectively) at $100 \mathrm{mM}$ concentration of Tris- $\mathrm{HCl}$ buffer of $\mathrm{pH} 7.5$ (Figure 9).

\section{Effect of reaction temperature}

The assay of purified and commercial collagenase was carried out at various incubation temperatures (25-70 oC). The maximum enzyme activity was found $1.36 \mathrm{U} / \mathrm{mL}$ at $45{ }^{\circ} \mathrm{C}$ and $1.41 \mathrm{U} / \mathrm{mL}$ at $50{ }^{\circ} \mathrm{C}$ using collagen substrate in $50 \mathrm{mM}$ Tris- $\mathrm{HCl}$ buffer, $\mathrm{pH} 8.5$ for purified and commercial collagenase (Figure 10). The enzyme activity was found to increase with the increase in reaction temperature upto $45^{\circ} \mathrm{C}$. The maximum enzyme activity was found $1.18 \mathrm{U} / \mathrm{mLat} 45^{\circ} \mathrm{C}$ and $1.44 \mathrm{U} / \mathrm{mL}$ at $50^{\circ} \mathrm{C}$ using gelatin substrate. The activity was reduced with further increase in the reaction temperature (Figure 11).

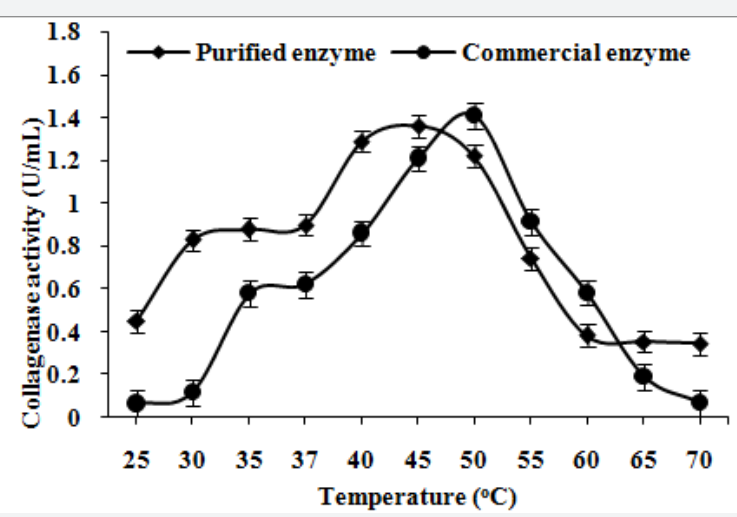

Figure 10: Effect of incubation temperature on activity of purified and commercial collagenase with collagen substrate.

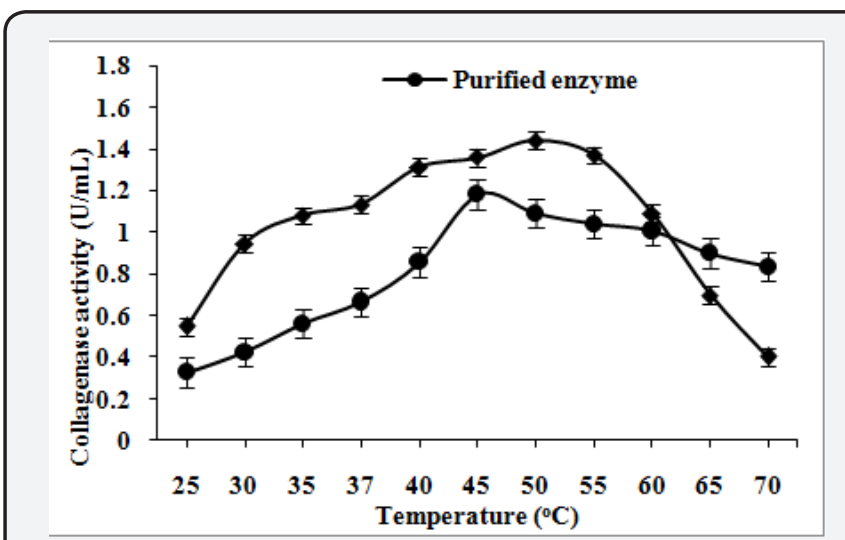

Figure 11: Effect of incubation temperature on activity of purified and commercial collagenase with gelatin substrate.

\section{Effect of incubation time}

In order to obtain the optimum incubation time for purified and commercial collagenase, the reaction mixture was incubated at $45^{\circ} \mathrm{C} \& 50^{\circ} \mathrm{C}$, for 5 to $60 \mathrm{~min}$ respectively. The optimum reaction time was found $30 \mathrm{~min}(1.29 \mathrm{U} / \mathrm{mL}) \& 20 \mathrm{~min}(1.24 \mathrm{U} / \mathrm{mL})$ for purified and commercial collagenase with collagen substrate (Figure 12) while time of reaction reduce to $20 \& 10 \mathrm{~min}$ for purified and commercial collagenase with gelatin substrate. The maximum en- 
zyme activity obtained was $1.68 \mathrm{U} / \mathrm{mL}$ and $5.30 \mathrm{U} / \mathrm{mL}$, respectively (Figure 13).

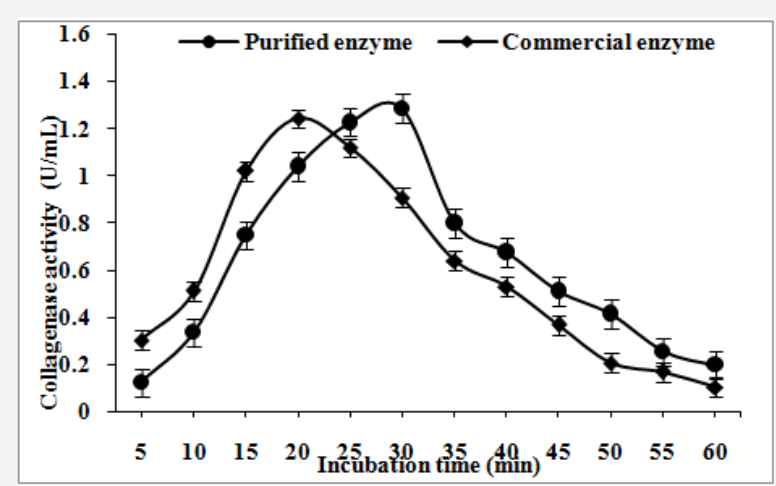

Figure 12: Optimization of incubation time using collagen substrate.

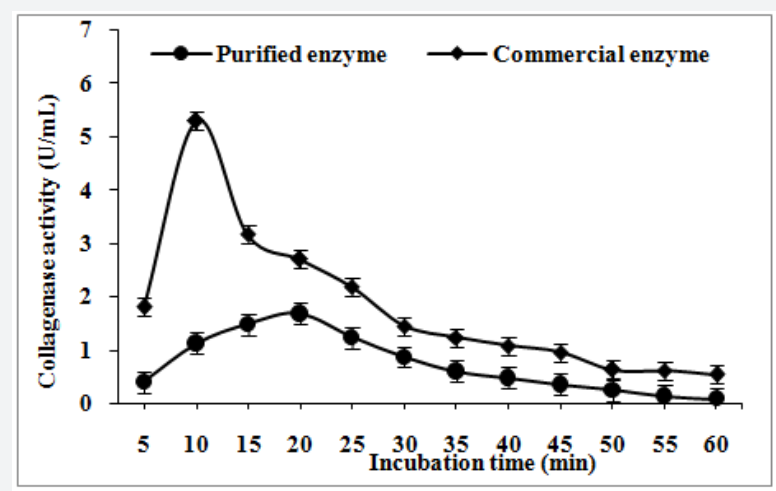

Figure 13: Optimization of incubation time using gelatin substrate.

\section{Substrate specificity}

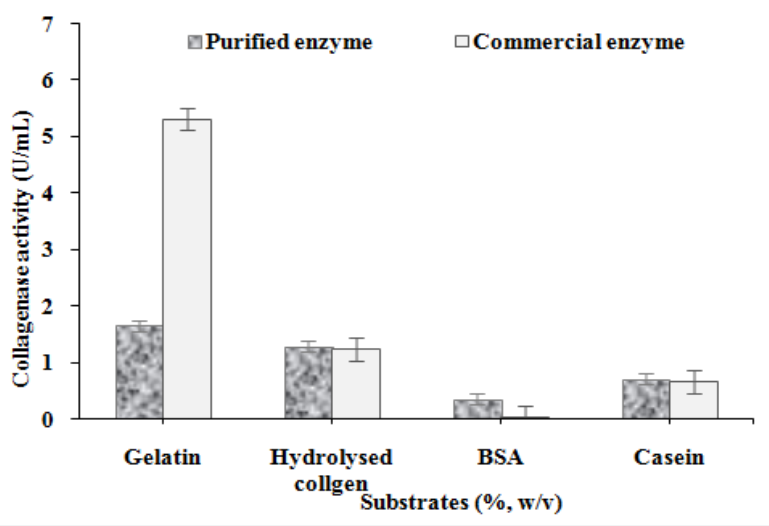

Figure 14: Effect of different substrates on purified and commercial collagenase.

Four substrates such as gelatin, collagen, BSA and casein were used and maximum collagenase activity was found $1.69 \mathrm{U} / \mathrm{mL}$ and $5.30 \mathrm{U} / \mathrm{mL}$ using gelatin substrate for purified and commercial enzyme (Figure 14). Moreover, good results were obtained when hydrolysed collagen was used as substrates for purified (1.29U/ $\mathrm{mL})$ and commercial $(1.25 \mathrm{U} / \mathrm{mL})$ collagenase. The results showed that collagenase of Clostridium origin did not digest BSA but purified collagenase hydrolysed effectively BSA as well as collagen. Purified enzyme has both collagenolytic and proteolytic activities. Gelatin and collegen substrate was found specific for collagenase activity.

\section{Kinetic properties of purified and commercial collage- nase}

The Km \& Vmax was determined using different concentrations [0.1 to $1.0 \%(\mathrm{w} / \mathrm{v})]$ of collagen and gelatin substrates. The purified enzyme was incubated for $20 \mathrm{~min}$ at 45 oC to calculate $\mathrm{K}_{\mathrm{m}} \& \mathrm{~V}_{\max }$. The $\mathrm{K}_{\mathrm{m}} \& \mathrm{~V}_{\max }$ values calculated from Lineweaver-Burk plot for the purified collagenase and were found $1.65 \mathrm{mg} / \mathrm{mL}$ and $2.12 \mathrm{U} / \mathrm{mL}$, respectively, using collagen substrate (Figure 15). While $6.60 \mathrm{mg} / \mathrm{mL} \& 6.58 \mathrm{U} / \mathrm{mL}$, respectively, with gelatin substrate (Figure 16). The values of $\mathrm{K}_{\mathrm{m}} \& \mathrm{~V}_{\max }$ were also calculated for commercial collaegenase using both substrates and were found $14.4 \mathrm{mg} / \mathrm{mL} \& 14.95 \mathrm{U} / \mathrm{mL}$ with collagen (Figure 17) and $10.17 \mathrm{mg} / \mathrm{mL} \& 30.48 \mathrm{U} / \mathrm{mL}$ with gelatin respectively, (Figure 18).

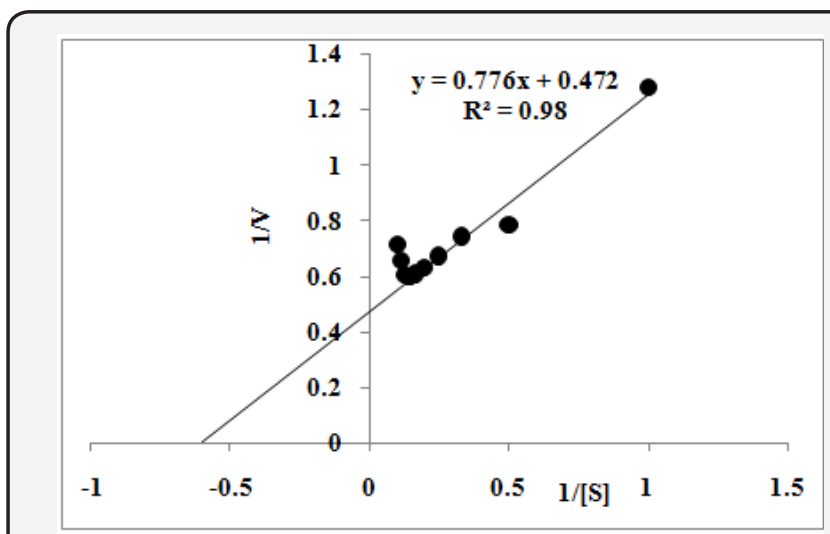

Figure 15: Lineweaver-Burk plot for the purified collagenase with collagen substrate.

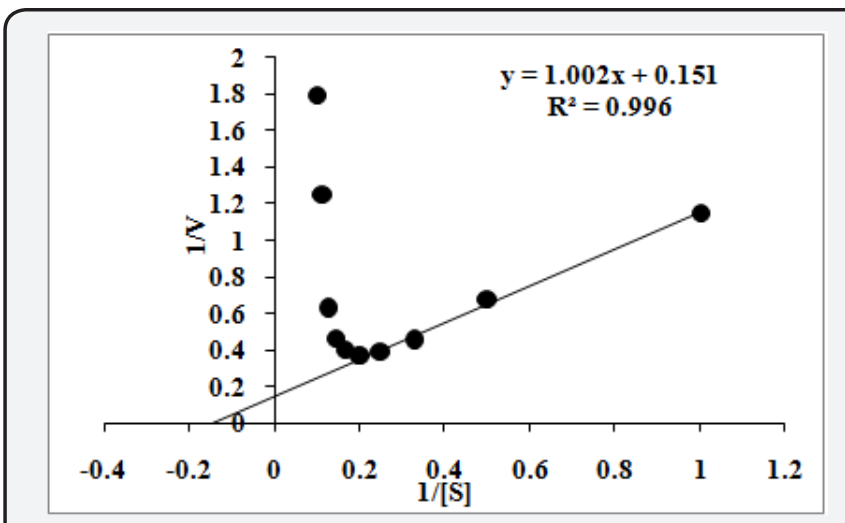

Figure 16: Lineweaver-Burk plot for the purified collagenase with gelatin substrate. 


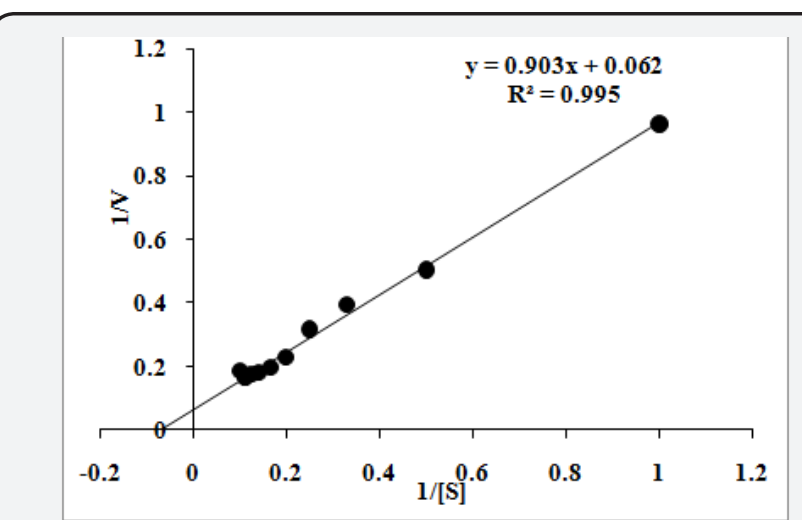

Figure 17: Lineweaver-Burk plot for the commercial collagenase with collagen substrate.

Effect of metal ions, inhibitors and additives on collagenase activity

Generally, metal ions act as cofactors for many enzymes. In order to establish the role of metal ion as a cofactor for purified collagnease various metal ions and inhibitors $\left(\mathrm{K}+, \mathrm{Ca}_{2}+, \mathrm{Fe}_{2}+, \mathrm{Mg}_{2}+\right.$,

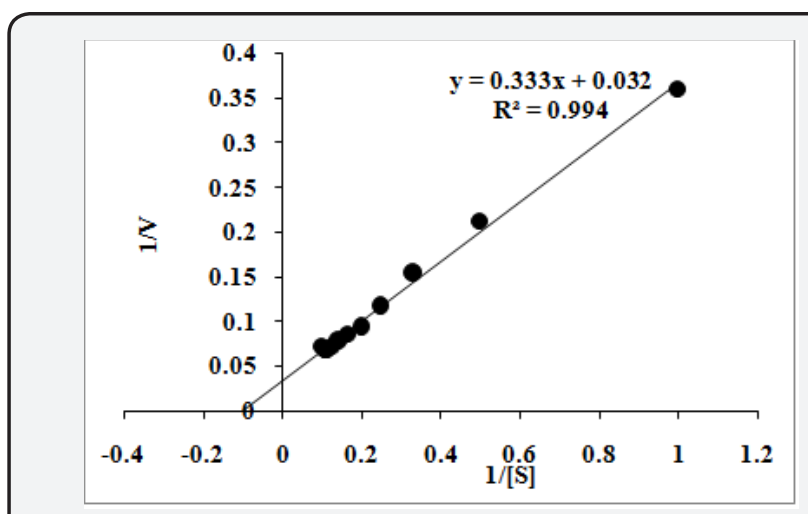

Figure 18: Lineweaver-Burk plot for the commercial collagenase with gelatin substrate.

$\mathrm{Zn}_{2}+, \mathrm{Co}_{2}+, \mathrm{Cu}_{2}+, \mathrm{Na}+, \mathrm{Ag}_{2}+, \mathrm{Hg}_{2}+, \mathrm{Pb}_{2}+$, Urea, SDS, PEG, DTT, EDTA and PMSF at concentration of $1 \mathrm{mM}$ in the reaction mixture. The enzyme activity was strongly inhibited by $\mathrm{Hg}_{2}+\mathrm{Pb}_{2}+$, EDTA, DTT and significant negative effect was also observed by $\mathrm{Fe}_{2}+, \mathrm{Cu}_{2}+$ and $\mathrm{Co}_{2}+$ (Table 2).

Table 2: Effect of metal ions, inhibitors and additives on collagenase activity using collagen and gelatin substrate.

\begin{tabular}{|c|c|c|c|c|c|}
\hline \multirow[t]{2}{*}{ S.No. } & \multirow[t]{2}{*}{ Metal ions (1mM) } & \multicolumn{2}{|c|}{ Purified enzyme relative activity (\%) } & \multicolumn{2}{|c|}{ Commercial enzyme relative activity (\%) } \\
\hline & & Collagen & Gelatin & Collagen & Gelatin \\
\hline 1 & $\mathrm{Na}^{+}$ & 85 & 87 & 83 & 81 \\
\hline 2 & $\mathrm{~K}^{+}$ & 22 & 17 & 76 & 67 \\
\hline 3 & $\mathrm{~Pb}^{+}$ & 3 & 13 & - & - \\
\hline 4 & $\mathrm{Zn}^{2+}$ & 102 & 101 & 101 & 103 \\
\hline 5 & $\mathrm{Hg}^{2+}$ & 9 & 2 & 9 & - \\
\hline 6 & $\mathrm{Ca}^{2+}$ & 121 & 112 & 123 & 112 \\
\hline 7 & $\mathrm{Mg}^{2+}$ & 99 & 100 & 95 & 93 \\
\hline 8 & $\mathrm{Co}^{2+}$ & 74 & 72 & 84 & 76 \\
\hline 9 & $\mathrm{Ag}^{2+}$ & 3 & 12 & 54 & 47 \\
\hline 10 & $\mathrm{Fe}^{2+}$ & 19 & 19 & 46 & 47 \\
\hline 11 & $\mathrm{Cu}^{2+}$ & 84 & 85 & 85 & 89 \\
\hline 12 & Urea & 16 & 6 & 89 & 74 \\
\hline 13 & SDS & 55 & 54 & 68 & 70 \\
\hline 14 & PMSF & 55 & 6 & 59 & 76 \\
\hline 15 & PEG & 113 & 110 & 112 & 113 \\
\hline 16 & DTT & 5 & - & 64 & - \\
\hline 17 & EDTA & - & - & - & - \\
\hline 18 & Control & 100 & 100 & 100 & 100 \\
\hline
\end{tabular}

\section{Acknowledgement}

We would like to thank Department of Biotechnology, Himachal Pradesh University for providing necessary facility.

\section{References}

1. Hay ED (1984) Cell-matrix interaction in the embryo: cell shape, cell surface, cells Skeltons, and their role in differentiation. In: Trelstad RL and Alan R Liss (Eds.), The role of extracellular matrix in development. New York, USA, pp. 1-31.
2. Harris ED, Cartwright EC (1977) Mammalian collagenases, chapter 6, in Proteases in Mammalian Cells and Tissue, Barrett AJ (Ed), North Holland, Netherlands, pp. 249-284.

3. Peterhofsky B (1982) Bacterial collagenase. Methods Enzymol 82: 453-471.

4. Mookhtiar K, Steinbrink SD, Van Wart HE (1985) Mode of hydrolysis of collagen-like peptidase by class I and class II Clostridium histolyticum collagenases: Evidence for both indopeptidase and tripeptidylcarboxypeptidase activities. Biochemistry 24: 6527-6533. 
5. Foegeding EA, Larick DK (1986) Tenderization of beef with bacterial collagenase. Meat Sci 18: 201-214.

6. Cronlund AL, Woychik JH (1987) Solubilization of collagen in restructured beef with collagenases and $\alpha$-Amylase. J Food Sci 52: 857 860 .

7. Goshev IA, Gousterova E, Vasileva-Tonkova, Nedkov P (2005) Characterization of the enzyme complexes produced by two newly isolated thermophylic actinomycete strains during growth on collagenrich materials. Proc Biochem 40: 1627-1631.

8. Kanth SV, Venba R, Madhan B, Chandrababu NK, Sadulla S (2008) Studies on the influence of bacterial Collagenase in leather dyeing. Dyes and Pigments 76(2): 338-347.

9. Agren MS, Taplin CJ, Woessner JF, Eagistein WH, Mertz PM (1992) Collagenase in wound healing: Effect of wound age and type. J Invest Dermatol 99: 709-714.

10. Pullen R, Popp R, Volkers P, Fusgen I (2002) Prospective randomized double-blind study of the wound-debriding effects of collagenase and fibrinolysin/deoxyribonuclease in pressure ulcers. Age Ageing 31 : 126-130.

11. Shmoilov AM, Rudenskaya GN, Isev VA, Baydakov AV, Zhantiev RD (2006) A comparative study of Collagenase complex and new homogeneous Collagenase preparations for scar treatment. J Drug Delivery Sci Technol 16: 285-292.

12. Klock G, Kowalsk MB, Hering BJ, Eiden ME, Weidemann A, et al. (1996) Fractions from commercial Collagenase preparations: Use in enzymic isolation of the islets of Langerhans from porcine pancreas. Cell Transplant 5: 543-551.

13. Kin T, Zhai X, Murdoch TB, Salam A, Shapiro J, et al. (2007) Enhancing the success of human islet isolation through optimization and characterization of pancreas dissociation enzyme. Amer J Transplant 7: 1233-1241.

14. Finland M, Jones WF, Barnes MW (1959) Occurrence of serious bacterial infections since the introduction of antibacterial agents. J Amer Med Ass 170: 2188-2197.

15. Iococca VF, Sibinga MS, Barbero GJ (1963) Respiratory tract bacteriology in cystic fibrosis. Amer J Dis Child 106: 315-324.

16. Nagano H, Kim A (2000) Purification of Collagenase and specificity of its related enzyme from Bacillus subtilis FS-2. Biosci Biotechnol Biochem 63(1): 181-183.

17. Rosen $H$ (1957) A modified ninhydrin colorimetric analysis for amino acids. Arch Biochem Biophy 67: 10-15.

18. Endo A, Murakawa S, Shimizu H, Shiraishi Y (1987) Purification and Properties of Collegenase from a Streptomyces Sp. J Bacteriol 102: 163-170.

19. Bradford MM (1976) A rapid and sensitive method for the quantitation of microgram quantities of protein utilizing the principle of proteindye binding. Anal Biochem 72: 248.

20. Laemmli UK (1970) Cleavage of structural protein during the assembly of the head of bacteriophage T4. Nature 227: 680-685.

21. Bollag DM, Edelstein SJ (1996) Protein Methods. In: John Wiley A and Sons (Eds.), John Wiley A and Sons Inc. Publications, $\left(2^{\text {nd }}\right.$ edn), USA, pp. 96-139.

22. Kristjansson MM, Cudmundsdotti S, Fox JW, Bjarnason JB (1995) Characterization of a collagenolytic serine proteinase from the Atlantic cod (Gadus morhua). Comp Biochem Physiol 110B: 707-717.

23. Sakurai Y, Inoue H, Nishii W, Takahashi T, Iino Y, et al. (2009) Purification and Characterization of a Major Collagenase from Streptomyces parvulus. Biosci Biotechnol Biochem 73: 21-28.

24. Kim SK, Park PJ, Kim JB, Shahidi F (2002) Purification and characterization of a collagenolytic protease from the filefish, Novoden modestrus. J Biochem Molecular Biol 335: 165-171.

\section{Your next submission with Juniper Publishers will reach you the below assets}

- Quality Editorial service

- Swift Peer Review

- Reprints availability

- E-prints Service

- Manuscript Podcast for convenient understanding

- Global attainment for your research

- Manuscript accessibility in different formats

( Pdf, E-pub, Full Text, Audio)

- Unceasing customer service

Track the below URL for one-step submission https://juniperpublishers.com/online-submission.php 